\title{
HABITAT DISTURBANCE AND SMALL MAMMAL RICHNESS AND DIVERSITY IN AN ATLANTIC RAINFOREST AREA IN SOUTHEASTERN BRAZIL
}

\author{
VERA Y CONDE, C. F. and ROCHA, C. F. D. \\ Departamento de Ecologia, Instituto de Biologia Roberto Alcantara Gomes, Universidade do Estado do Rio de Janeiro, \\ R. São Francisco Xavier 524, CEP 20550-013, Rio de Janeiro, RJ, Brazil \\ Correspondence to: Carlos Frederico Duarte Rocha, Departamento de Ecologia, \\ Instituto de Biologia Roberto Alcantara Gomes, Universidade do Estado do Rio de Janeiro, R. São Francisco Xavier 524, \\ CEP 20550-013, Rio de Janeiro, RJ, Brazil, e-mail: cfdrocha@uerj.br
}

Received August 9, 2004 - Accepted November 5, 2004 - Distributed November 1, 2006

(With 1 figure)

\begin{abstract}
Since disturbance is an important ecological factor affecting species diversity in natural environments, the increasing human occupation rate in Brazilian Atlantic rainforest, which supports about $50 \%$ of Brazil's human population, has resulted in intense habitat degradation and fragmentation. Within this rainforest, animal and plant species have been lost at a high rate, and biological and diversity is presently vulnerable. Various animals community studies along a gradient of environmental disturbances have shown that the highest species diversities occur in habitats with intermediate levels of disturbance frequency and intensity. In the present study, which was carried out in the Atlantic forest of Ilha Grande (23 $11^{\prime} \mathrm{S}$ and $44^{\circ} 12^{\prime} \mathrm{W}$ ), an island located on the southern coast of Rio de Janeiro State, southeastern Brazil, we estimated species richness, diversity, and abundance of small mammals in three forest areas having different disturbance levels. This was done, in each of these areas and in an anthropic area that they surround, by establishing trails $200 \mathrm{~m}$ long, in which points were marked at $20 \mathrm{~m}$ intervals. The work involved a total effort of 4800 trap/nights. We also measured some habitat variables at each site in order to evaluated their disturbance levels. Our data showed that the two most conserved forests had the lower species richness and small mammal diversity, while in the anthropic area wild species were absent. The forest with an intermediary level of disturbance showed higher values for species richness and diversity, with the anthropic area presenting the highest disturbance level.
\end{abstract}

Keywords: habitat disturbance, small mammal diversity, species richness, Atlantic rainforest.

\section{RESUMO}

\section{Distúrbio no habitat e riqueza e diversidade de pequenos mamíferos em uma área de Mata Atlântica no sudeste do Brasil}

Os distúrbios são importantes fatores ecológicos afetando a diversidade de espécies em ambientes naturais. Na Floresta Atlântica vive cerca de 50\% da população humana do Brasil. A crescente ocupação humana neste ecossistema, resultou em uma intensa degradação e fragmentação do hábitat, tornando vulnerável a sua diversidade biológica e ocasionando uma alta taxa de perda de espécies animais e vegetais. Alguns estudos de comunidades têm demonstrado que ao longo de um gradiente de perturbação ambiental, os maiores valores de diversidade de espécies são encontrados em hábitats com níveis intermediários de frequência e de intensidade de distúrbios. No presente estudo, nós estimamos a riqueza, diversidade e abundância de espécies de pequenos mamíferos em três áreas de Mata Atlântica com diferentes níveis de distúrbio. O estudo foi conduzido na Mata Atlântica da Ilha Grande (23 $11^{\prime}$ ' S e $44^{\circ} 12^{\prime}$ W), uma ilha localizada no Sul do estado do Rio de Janeiro, Sudeste do Brasil. Em cada uma das três áreas de florestas e em uma área antrópica rodeada por estas florestas, nós estabelecemos 10 trilhas paralelas com 200 metros 
de comprimento (com pontos a cada $20 \mathrm{~m}$ de intervalo e pontos adicionais acima do solo), num esforço total de 4800 armadilhas/noite. Nós também medimos algumas variáveis estruturais do hábitat para avaliar o nível de distúrbio em cada área. Nossos dados mostraram que as duas florestas mais conservadas tiveram os mais baixos valores de riqueza e diversidade de espécies e que na área antrópica ocorreu uma perda quase total de espécies silvestres. A floresta com nível intermediário de distúrbio teve os maiores valores de riqueza e diversidade de espécies, considerando a área antrópica como um hábitat sob alto grau de distúrbio.

Palavras-chave: distúrbios no habitat, diversidade de pequenos mamíferos, riqueza de espécies, Mata Atlântica.

Disturbance is an important ecological factor affecting species diversity in natural environments (Sousa, 1984). These events can remove biomass, creating free substratum, and competition. Besides that, disturbances can be considered as events that promote alterations in systems structures, reduce species competition, and change resource availability (Sher et al., 2000). Variations in frequency and intensity may result in an increase or decrease of biological diversity (Connell, 1978), making them key factors in community structures (Lavorel et al, 1994; Armesto \& Pickett, 1985). The degradation of natural environments (e.g., deforestation) and fragmentation substantially modifies these structures and wild population parameters and, consequently, may affect species diversity (Law \& Dickman, 1998; Laurence \& Bierregaard, 1997; Lovejoy et al., 1986; Noss et al., 1994; Terborgh, 1992). It is also known that, in some cases, disturbances cause increased environmental heterogeneity which in turn may reduce the effects of interspecific competition, and enable coexistence of a larger number of ecologically similar species (Fonseca \& Robinson, 1990; Dueser \& Shugart, 1979; Price, 1978; M'Closkey, 1976; Rozensweig, 1995; Hulbert, 1971 apud Richards, 1969). This is especially true among small mammals, for whom habitat is the most important niche dimension by which species segregate (Schoener,1974).

Disturbances are heterogeneous in space and time (Sousa, 1984). For some community studies along a gradient of environmental disturbances, the highest species diversity occurred in habitats with intermediate levels of disturbance frequency and intensity (Connell, 1978; Grime, 1979). In these cases, tolerant species can survive in disturbed areas, along with species already present in the habitat (Connell, 1978).
The Brazilian Atlantic rainforest, despite concentrating one of the world's highest biological diversities, with approximately $7 \%$ of the planet's species (Quintela, 1990), is one of the most threatened biomes of the planet (Fonseca and Kierkulf, 1988), and one of the 25 global hotspots (Myers et al., 2000). Of its original coverage, which extended along almost all the Brazilian coast, roughly 7\% remains (Terghborg, 1992), of which only $1 \%$ retains its original state (Mittermeir et al., 1982). Increasing human occupation rates in this ecosystem, which supports about $50 \%$ of the Brazilian human population (Lino, 1992 apud Bergallo, 1994), has resulted in intense habitat degradation and fragmentation, which - besides causing a high rate of animal and plant species loss (Whitmore, 1997; Lino, 1992, apud Bergallo, 1994) - has rendered the remaining biological diversity vulnerable (Turner, 1996; Pimm and Askins, 1995). Presently 171 of the 246 threatened species of Brazilian vertebrate fauna occur in Atlantic rainforest (Lino, 1992 apud Bergallo, 1994), which also numbers 567 endemic vertebrates, of which 51 are endemic mammal species (Stevens \& Husband, 1998).

Ilha Grande, an island covered by Atlantic forest, is located off the southern coast of Rio de Janeiro State, southeastern Brazil, is one of the most important remnants of this biome. Alho et al. (2002) analyzed the conservation status of the Parque Estadual da Ilha Grande and concluded that the state of vegetation covering in the island remains comparatively better than that of the degraded Atlantic forest overall, making the island of special significance for ecological studies.

For hundred of years, many parts of Ilha Grande were extensively used for farming. But with the abandonment of agriculture after the area 
was transformed into a state park in 1971, the island is now characterized by a mosaic of different successional forest stages presenting various anthropic interference levels. Alho et al. (2002) estimated that approximately $52 \%$ of the vegetation covering in the island is partially disturbed whereas $46.7 \%$ continues undisturbed. This forest mosaic in Ilha Grande constitutes in effect a model by which to evaluate forest disturbance effects on biological diversity. In the present study we estimated species richness, diversity and abundance of small mammals in three forest areas presenting different disturbance levels in order to verify if comparatively higher species richness and diversity occur in areas with intermediary levels of disturbance.

\section{METHODOLOGY}

\section{Study area}

This study was carried out in Atlantic forest near the village of Dois Rios, which is located on Ilha Grande $\left(23^{\circ} 11^{\prime} \mathrm{S}\right.$ and $\left.44^{\circ} 12^{\prime} \mathrm{W}\right)$. Annual rainfall in the area is $c a .2,500 \mathrm{~mm}$ and mean annual temperature is $c a .23{ }^{\circ} \mathrm{C}$ (NUCLEN, 1998). The island has an area of approximately 19,000 ha and is one of the most important remnants of Brazilian Atlantic rainforest (Araújo \& Oliveira, 1988).

\section{Collecting methods and analysis}

We analyzed abundance, species richness, and diversity of the small mammal community in three Atlantic Forest areas, located in the southern part of Ilha Grande, that differ in disturbance level, and also in one anthropic area surrounded by these forests: (1) 25 year-old secondary forest (25 SF) - in a previously cleared area in which regeneration began 25 years ago; the canopy is about 12-15 $\mathrm{m}$ high, the trees have relatively narrow trunks (about 10-20 $\mathrm{cm}$ wide in diameter at breast height $(\mathrm{DBH})$; the understory is relatively dense and has a comparatively shallow leaf litter layer (5-15 mm); (2) 50 year-old secondary forest (50 SF) in an area in which previously existing small farms were abandoned approximately 50 years ago (in the late 40's); the canopy is $20-25 \mathrm{~m}$ high and most tree trunks are $20-40 \mathrm{~cm}$ wide $(\mathrm{DBH})$; the understory is comparatively less dense than that of SFR25; and (3) Undisturbed forest (UF) - having no evidence of human impact; canopy reaching 30-35 m in height with a relatively open understory; the forest is dense and the trunks of many trees reach $c a$. $1.4 \mathrm{~m}$ wide (DBH); leaf litter may reach $150 \mathrm{~mm}$ in depth; this area has a high bromeliad and liana density (Almeida et al. 1998).

To evaluate the effect on the small mammal community of a highly disturbed area surrounded by forests, we extended our sampling using the same trapping technique to the small mammals of the anthropic area of Dois Rios village. The village proper, which is surrounded by $25 \mathrm{SF}$ and $50 \mathrm{SF}$ forests, is located in the southern part of the island and is the site of most residential buildings, some of which have been abandoned. Today, the village has a population of about 170 people. All of the native vegetation of the village has been removed and replaced in some areas by exotic plants. The village area is either barren or covered by exotic and native herbs and shrubs and some portions are covered by regenerating vegetation. These places of the village have been abandoned in recent years.

To estimate abundance, richness and diversity of small mammals species in each area we delimited ten $120 \mathrm{~m}$ long trails, marked at $20 \mathrm{~m}$ intervals. We set small-mammal traps at 70 points on the ground at points marking the intervals. Ten additional points were randomly chosen at which we established traps attached to lianas or tree branches $1.5 \mathrm{~m}$ above ground,. fifty Movart traps and 30 Sherman traps with banana as bait were used. To factor out the effect of seasonality, all samplings were made from June to September (the dry season). At each site captures were made on 15 consecutive nights, except for the traps above ground, which remained open on only seven nights. The traps were checked every morning and the small mammals captured were identified, marked by ear perforation (according to a pre-determined number code - Bergallo, 1994), and released at the capture point. Abundance of individuals of each species at each site was estimated for each of the ten trails established. For abundance estimates we considered only first captures. Abundance for each site was considered as the mean of that obtained for all of the ten trails. Species diversity at each site was estimated using the Shannon-Wiener diversity index: $\mathrm{H}^{\prime}=-\Sigma p i \log _{\mathrm{e}} p i$ in which $p i$ is the proportion of individuals of the $\mathrm{i}$-th species in the sample (Magurran, 1988).

In order to estimate the disturbance level of the areas, we calculated productivity and an 
understore indexes using the mean values of the following variables:

Productivity index (based on Paglia et al., 1995):

(1) estimated percentage of canopy coverage (CC). To estimate this variable, the quadrate was positioned overhead, whereupon the observer counted the proportion of internal subdivisions occupied by the canopy. Coverage percentage for one point was expressed as the mean of 5 percentages obtained at each; (2) central trunk diameter (CDT) of standing trees close to the ground. Both of the variables were measured inside a $3 \mathrm{~m}$ radius at 30 different sampling points at each site; (3) DBHs of all trees in a $5 \mathrm{~m}$ radius of ten random sampling points at each site were tapemeasured to the nearest $2 \mathrm{~cm}$; and (4) the sum of plants at $0 \mathrm{~cm}$ (NP0), $50 \mathrm{~cm}$ (NP50), and $1 \mathrm{~m}$ (NP1) above ground, were estimated with a rod ( $1 \mathrm{~m}$ long) extended horizontally at these three heights. These variables were measured inside a $3 \mathrm{~m}$ radius at 30 different sampling points of each site, site using the following procedures:

Productivity Index: $\frac{\bar{x}_{C C}}{\sum \bar{x}_{C C}}+\frac{\bar{x}_{C D T}}{\sum \bar{x}_{C D T}}+\frac{\bar{x}_{D B H}}{\sum \bar{x}_{D B H}}$

Understory Index: $\quad \frac{\bar{x}_{N P 50}}{\sum \bar{x}_{N P 50}}+\frac{\bar{x}_{N P 1}}{\sum \bar{x}_{N P 1}}+\frac{\bar{x}_{N P 0}}{\sum \bar{x}_{N P 0}}$

where $\bar{x}$ is the mean value of the variables in each area and $\Sigma \bar{x}$ is the mean value of the variables in all areas.

\section{RESULTS}

The 60 nights of the study, which yielded a total effort $(4,480$ trap/nights), resulted in a $4.57 \%$ mean capture success. We caught 69 different individuals (in 205 captures) belonging to four Families (Didelphidae, Sciuridae, Muridae, and Echimydae) of two Orders (Didelphimorphia and Rodentia) of wild small mammals. Of these, three were rodent species (Trinomys iheringi, Sciurus aestuans, and Oxymycterus dasytrichus) and two were marsupials (Didelphis aurita and Marmosops incanus). Table 1 shows the number of individuals captured in, and total abundance of, each area. Species found in all three sites studied were Didelphis aurita and Trinomys iheringi. Oxymycterus dasytrichus occurred only in $25 \mathrm{SF}$. Sciurus aestuans was caught in $50 \mathrm{SF}$ and $25 \mathrm{SF}$.

The understory density was greater in $25 \mathrm{SF}$ and vegetative productivity higher in UF. Productivity and understory indexes for each site are presented in Table 2 .

Fig. 1 shows the estimated values of species richness, diversity, and mean abundance of small mammals for the three forest areas studied. Highest small mammal richness and diversity occurred in $25 \mathrm{SF}$ and highest abundance in $50 \mathrm{SF}$ (Fig. 1). Conversely, the lowest? values of small mammal species richness and diversity occurred in undisturbed forest (UF) (Fig. 1). In the anthropic area, the only wild species sampled was Didelphis aurita (one individual); besides that, 14 individuals of the exotic Mus musculus were caught in the traps.

\section{DISCUSSION}

In the forest habitats studied at Ilha Grande the small mammal species sampled were generally common to the three sites, with rodent abundance being higher than that of the marsupials. The

TABLE 1

Total number of individuals and abundance (based on marked individuals) of small mammal species captured in three areas sampled on Ilha Grande, southeastern Brazil ( $25 \mathrm{SF}=$ regenerating forest (25 years); $50 \mathrm{SF}=$ regenerating forest $(50$ years $)$; and $\mathrm{UF}=$ undisturbed forest .

\begin{tabular}{|l|c|c|c|}
\hline \multicolumn{1}{|c|}{ Species } & 25 SF & 50 SF & UF \\
\hline Didelphis aurita & 3 & 5 & 4 \\
\hline Marmosops incanus & 1 & 1 & 1 \\
\hline Sciurus aestuans & 7 & 8 & - \\
\hline Oxymycterus dasytrichus & 3 & - & - \\
\hline Trinomys iheringi & 5 & 15 & 16 \\
\hline Total & 19 & 29 & 21 \\
\hline
\end{tabular}


TABLE 2

Values of environmental variable indices in three areas sampled on Ilha Grande, southeastern Brazil: $25 \mathrm{SF}=$ regenerating (25 years) forest; $50 \mathrm{SF}=$ regenerating $(\mathbf{5 0}$ years $)$ forest; and $\mathrm{UF}=$ undisturbed forest.

\begin{tabular}{|c|c|c|}
\hline Area & Understory index & Productivity index \\
\hline $25 \mathrm{SF}$ & 2.77 & 2.32 \\
\hline $50 \mathrm{SF}$ & 2.71 & 3.18 \\
\hline UF & 2.51 & 3.29 \\
\hline
\end{tabular}

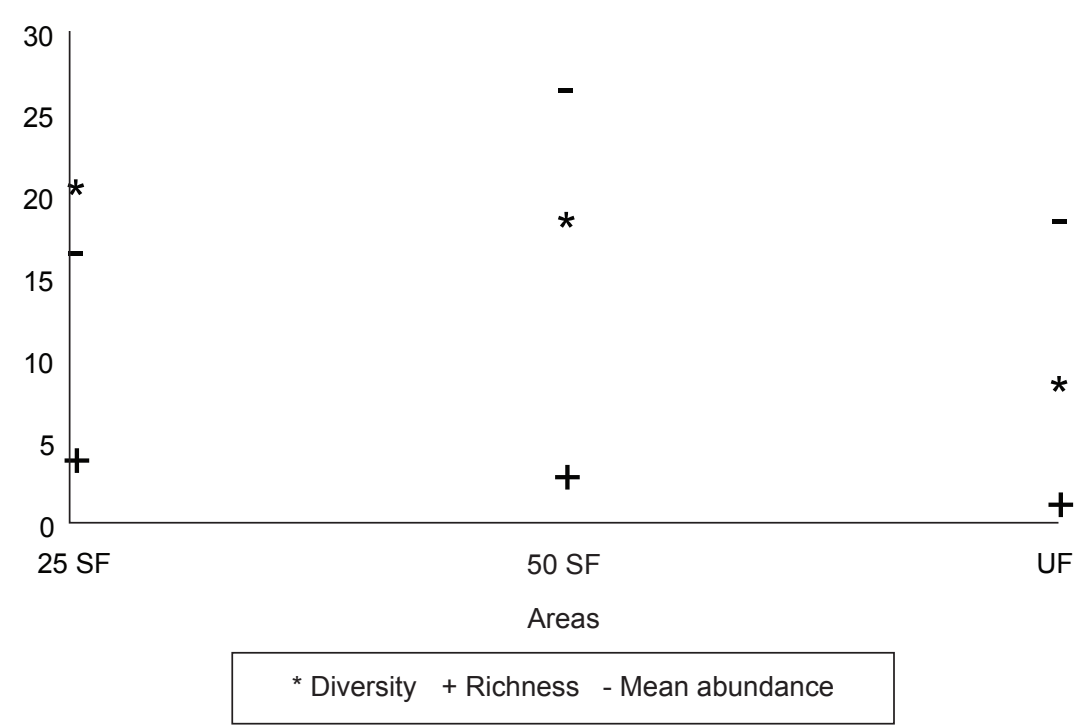

Fig 1. - Mean abundance, richness, and diversity of small mammal fauna in the three sampled areas on Ilha Grande, southeastern Brazil: $25 \mathrm{SF}=$ regenerating forest (25 years); $50 \mathrm{SF}=$ regenerating forest (50 years); and UF = undisturbed

anthropic area presented severely diminished small mammal fauna, with only one wild species caught (Didelphis aurita), which is also common in other altered forested areas of Ilha Grande (Alho et al., 2002) and in urban areas. The other species found at in the urban area was the exotic Mus musculus, an invader common on about $95 \%$ of oceanic islands (Alho et al., 2002).

Our data indicated a variation in some parameters of the small mammal community among habitats differing in disturbance level, i.e., small mammal diversity was comparatively lower in the undisturbed forest, whereas the higher values of abundance, richness, and diversity occurred in the forest areas with intermediate levels of disturbance (50 SF and $25 \mathrm{SF}$ ) if we consider the anthropic area as one additional level of disturbed area.
Areas with different disturbance levels usually vary in vegetational structure (Attiwill, 1994). Stallings et al. (1990) studied the effect of human disturbance in a small mammal community in an Atlantic rainforest area and suggested the basal area of trees as a good index of disturbance level. Also, the basal area can increase site availability for breeding, foraging, and providing refuge for small mammals (Alho, 1981). Besides that, in successional forest stages differences are found in habitat structure, e.g., in the early stages a comparatively higher understory cover and trees with narrow trunks and less canopy coverage are expected, in contrast with those found in mature forest. Our data of productivity and undestorey indexes were consistent with this expectation. 
Connell, 1978 proposed that intermediate levels of impact would result in an increase of biological diversity in communities of tropical trees and coral reefs. On the other side, Wylie \& Currie (1993) suggested that the species-energy theory (which proposes that the species richness in a particular area is limited by the amount of available energy) could be applied to small mammal communities explaining approximately 70 to $76 \%$ of the variation in the species richness in different areas. However, habitats with high productivity and consequently higher amount of avaiable energy, are less heterogeneous and as the variety of resources available decrease, the species diversity would decrease accordingly (Rozensweig, 1996). As a result the higher values of species diversity are expected in habitats with intermediate productivity (Rozensweig, 1971). Primary forests are relatively homogeneous habitats (Fonseca, 1989) where it is expected to occur a high primary productivity (Mabberley, 1983). Our results agree with the trend that more disturbed habitats tend to be more heterogeneous whereas undisturbed forest areas usually tend to be more productive and homogeneous. For small mammals, space seems to be the main niche dimension to allow the coexistence of ecologically similar species (Schoener, 1974). The spatial heterogeneity may result in an increase in the diversity of resources available in a particular habitat making the coexistence of a large number of species feasible (Simpson, 1964; Richards, 1969; apud Paglia et al., 1995). An increase in the level of spatial heterogeneity in a particular habitat may also diminish the rate of interspecific encounters, reducing the effects of competition (Hulbert, 1971 apud Richards, 1969). Small mammal microhabitat segregation has been indicated to be an important force in the small mammal communities structure (e.g. Kadmon, 1993; Duplessis \& Kerley, 1991; Christian, 1980; Alho, 1978). Habitats having some level of disturbance increase in environmental heterogeneity (Lambeck \& Saunders, 1993 apud Law \& Dickman, 1998) resulting in higher number of microhabitats available to sympatric species (Scott et al. 1982; Crawford et al, 1981 apud Yahner, 1986; Yahner, 1984). Stallings et al. (1990) studying an Atlantic rainforest area in Southeastern Brazil found an increase of small mammal diversity as a function of the habitat heterogeneity caused by fire (where antropic disturbances created many environments, increasing especially the number of terrestrial rodents). According to Fonseca (1989), the more homogeneous primary forests tend to have lower small mammal diversity and species richness, while those of large heterogeneous areas tend to be higher. Furthermore, the small mammal communities of intermediary-stage secondary forests of Brazilain coastal regions have higher richness and diversity than mature forests, because forest structures with developed understory favor a high degree of habitat segregation, increasing local diversity (Fonseca \& Robinson, 1990). Our results are consistent with those of Fonseca (1989) for other Brazilian Atlantic rainforest areas and also with those of Bonvicino et al. (1997) for the cerrado of central Brazil. Both studies found that higher species richness and diversity of small mammals occurred in areas with some level of disturbance rather than in undisturbed forest. However, a local increase in species diversity does not necessarily imply a regional-scale increase, and although destruction of natural environments may favor a higher number of species, at the same time many of them - specially those who use the specialized microhabitats in the forest may disappear. For endemic species in natural environments, anthropic disturbances - whether by deforestation, pollution, or species introduction are novel in evolutionary terms, and their long-term consequences may be disastrous.

Acknowledgments - This study is part of the results of the Program for Ecology, Conservation and Management of the Southeastern Brazilian Ecosystems and of the Southeastern Brazilian Vertebrate Ecology Project (Vertebrate Ecology Laboratory), both of the Instituto de Biologia, Universidade do Estado do Rio de Janeiro. The Graduate Program in Biology of the Universidade do Estado do Rio de Janeiro provided financial support for the study. We thank the Coordination of CEADS/ UERJ and the Director of Regional Campi for local support and for making many of the university's facilities available for our use. We also thank the Sub-Reitoria de Pós-Graduação e Pesquisa (SR-2/UERJ) for institutional support. Emerson B.Bittencourt and Davi M. Azevedo-Martins assisted in fieldwork. Helena G. Bergallo, Monique Van Sluys and Davor Vrcibradic kindly read the manuscript offering helpful suggestions. During the study C. F. Vera y Conde and C. F.D Rocha (Processes No. 307 653/2003-0 and 477981/2003-8) received research grants from the Conselho Nacional de Desenvolvimento Científico e Tecnológico - CNPq.

\section{REFERENCES}

ALHO, C. J. R., SCHNEIDER, M. \& VASCONCELLOS, L. A., 2002, Degree of threat to the biological diversity in the Ilha 
Grande State Park (RJ) and Guidelines for conservation. Brazilian Journal of Biology, 62: 375-385.

ALHO, C. J. R., 1981, Small mammal population of brazilian cerrado: The dependence of abundance and diversity on habitat complexity. Revista Brasileira de Biologia, 41: 223-230.

ALHO, C. J. R., 1978, Ecological space and distribution of small mammals in different habitats. Revista Brasileira de Zoolologia, 38: 693-705.

ALMEIDA, D. R., COGLIATTI, L. \& ROCHA, C. F. D., 1998, As bromeliáceas da Mata Atlântica da Ilha Grande, RJ: Composição e diversidade de espécies em três ambientes diferentes. Bromelia, 5: 54-56.

ARAUJO, D. S. \& OLIVEIRA, R. R., 1988, Reserva Biológica Estadual da Praia do Sul (Ilha Grande, Rio de Janeiro):lista preliminar da flora. Acta Bot. Bras., 1: 83-94.

ARMESTO, J. J. \& PICKETT, S. T. A., 1985, Experiments on disturbance in old-field plant communities: Impact on species richness and abundance. Ecology, 66: 230-240.

ATTIWILL, P. M., 1994, The disturbance of forest ecosystems: The ecological bases for conservative management. Forest Ecology and Management, 63: 247-300.

BERGALLO, H. G., 1994, Ecology of small mammal community in an Atlantic Forest area in Southeastern Brazil. Studies on Neotropical Fauna and Environment, 29:197-217.

BONVICINO, C. R., FREITAS, S. R. \& D'ANDREA, P. S., 1997, Influence of bordering vegetation, width, and state of conservation of gallery forest on the presence of small mammals. pp. 164-167. In: L. L. Leite \& C. H. Saito (eds.). Contribuição ao conhecimento do Cerrado. Brasília.

CONNELL, J. H., 1978, Diversity in Tropical Rain Forests and Coral Reefs - High diversity of Trees and Corals is Maintained Only in a Non-Equilibrium State. Science, 199: 1302-1310.

CHRISTIAN, D. P., 1980, Vegetative Cover, Water Resources and Microdistributional Patterns in a Desert Rodent Community. Journal of Animal Ecol., 49: 807-816.

DUESER, R. D. \& SHUGGART, H. H., 1979, Niche Pattern in Forest-floor in Small Mammal Fauna. Ecology, 60: 108-118.

DUPLESSIS, A. \& KERLEY, G. H. I., 1991, Refuge Strategies and Habitat Segregation in two sympatric rodents Otomys unisulcatus and Paratomys brantsii. J. Zool. Lon., 224: 1-10.

FONSECA, G. A. B. \& ROBINSON, J., 1990, Forest size and structure: competitive and predatory effects on small mammals communities. Biological Conservation, 53: $265-284$.

FONSECA, G. A. B., 1989, Small mammal species diversity in brazilian tropical primary and secondary forests of different sizes. Revista Brasileira de Zoologia, 6: 381-422.

FONSECA, G. A. B. \& KIERKULFF, M. C. M., 1988, Biology and natural history of Brazilian Atlantic Forest small mammals. Bull. Florida State Museum Biol. Sci., 34: $99-152$

GRIME, J. P., 1979, Plant strategies and vegetational processes. J. Wiley, New York, USA in Armesto, J. J. \& Pickett, S. T. A.,1985, Experiments in old-field plant communities:
Impact on species richness and abundance. Ecology, 66: $230-240$.

HULBERT, S. H., 1971, The non concept of species diversity: a critique and alternative parameters. Ecology 52: 578-586, In: Richards, P. W., 1969, Speciation in the tropical rain forest and the concept of the niche. Biol. Linn. Soc., 149-153.

KADMON, R., 1993, Population Dynamic consequences of habitat heterogeneity: an experimental study. Ecology, 74: 816-825.

LAMBECK, R. J. \& SAUNDERS, D. A., 1993, The role of patchiness in reconstructed wheatbelt landscapes. In Nature Conservation 3: Reconstruction of fragmented ecosystems. Saunders D.A., Hobbs R., Ehrlich, P. (eds.) pp 153-161. Sydney: Surrey Beatty and Sons. In: Law, BS and Dickman, CR (1998): The use of habitat mosaics by terrestrial vertebrate fauna: implications for conservation and management. Biodiversity and Conservation, 7: $323-333$.

LAURENCE, W. F. \& BIERREGAARD, R. O. Jr., 1997, Tropical forest remnants. The University of Chicago Press, pp. 502-514. In: W. F. Laurance \& R. O. Bierregaard Jr. (eds.), Tropical forest remnants: ecology, management, and conservation of fragmented communities. University of Chicago Press.

LAVOREL, S., LEPART, J., DEBUSSCHE, M., LEBREDON, J. D. \& BEFFY, J. L., 1994, Small scale disturbance and the maintenance of species diversity in a Mediterranean old field. Oikos (Berl.), 70: 455-473.

LAW, B. S. \& DICKMAN, C. R., 1998, The use of habitat mosaics by terrestrial vertebrate fauna: implications for conservation and management. Biodiversity and Conservation, 7: 323-333.

LINO, C. F., 1992, Reserva da biosfera da Mata Atlântica. Plano de ação, vol.1: Referências básicas. Consórcio Mata Atlântica. Universidade Estadual de Campinas. In: Bergallo, H. G., 1994. Ecology of a small mammal community in an Atlantic Forest area in Southeastern Brazil. Studies on Neotropical fauna and environment, 29: 197-217.

LOVEJOY, T. E. R., BIERREGAARD, R. O., Jr., RYLANDS, A. B., MALCOLM, J. R., QUINTELA, C. E., HARPER, L. H., Jr., BROWN, K. S., POWELL, A. H., POWELL, G. U. N., SCHUBERT, H. O. R. \& HAYS, M. B., (1986): Edge effects and other effects of isolation an Amazon forest fragments. pp. 257-285. In: Soulé, ME (ed). Conservation Biology: The science of scarcity and diversity. Sinauer, Sunderland, Massachusetts.

MABBERLEY, D. J., 1983, Tropical Rain Forest Ecology. Chapman \& Hall, New York, 156 p.

MAGURRAN, A., 1988, Ecological diversity and its measurement. Australia: Croon Helm Ltd. Australia, $179 \mathrm{p}$.

M'CLOSKEY, R. T., 1976, Community structure in simpatric rodents. Ecology, 57: 728-739.

MITTERMEIER, R. A., COIMBRA-FILHO, A. F., CONSTABLE, I. D., RYLANDS, A. B. \& VALLE, C. M., 1982, Conservation of primates in the Atlantic Forest of Brazil. Int. Zoo. Yearbook, 22: 2-7. 
MYERS, N., MITTERMEIER, R. A, MITTERMEIER, C. G., FONSECA, G. A. B., KENT, J. 2000, Biodiversity Hotspots For Conservation Priorities. Nature, 403: 853-858.

NOSS, R. F., 1994, Habitat Fragmentation in Meffi and Carroll (eds.). Principles of Conservation Biology. Sinauer Associates, Massachusetts, pp. 237-264.

NUCLEN, 1998, Estação Meteorológica da Central Nuclear de Angra, Eletronuclear, Gerência de Gestão Ambiental, Angra dos Reis, Rio de Janeiro.

PAGLIA, A. P., DE MARCO, P. Jr., COSTA, F. M, PEREIRA, R. F. \& LESSA, G., 1995, Heterogeneidade estrutural e diversidade de pequenos mamíferos em um fragmento de mata secundária em Minas Gerais. Revista Brasileira de Zoologia, 12: 67-79

PIMM, S. L., RUSSELl, G. S., GITTLEMAN, S. L. \& BROOKS, F. M., 1995, The Future of Biodiversity. Science, 269: 347-350.

PRICE, M. V., 1978, The role of microhabitat in structuring desert rodent communities. Ecology, 59: 910 - 921.

QUINTELA, C. E., 1990, An S.O.S. for Brazil's beleaguered Atlantic Forest. Nature Conservancy Magazine 40: 14-19. In: Stevens, S. M. \& T. P. Husband, 1998. The Influence of edge on small mammals: evidence from Brazilian Atlantic orest fragments. Biological Conservation, 85: 1-8.

RICHARDS, P. W., 1969, Speciation in the Tropical Rain Forest and the concept of the niche, Biol. J Linn. Soc. 1: 149-153. In: Paglia, AP, De Marco, P. J., Costa, FM, Pereira, R F, Lessa, G, (1995): Heterogeneidade estrutural e diversidade de pequenos mamíferos em um fragmento de mata secundária em Minas Gerais. Revista Brasileira de Zoologia, 12: 67-79.

ROSENZWEIG, M. L., 1995, Species diversity in space and time. Cambridge University Press, Second edition, 436 p.

ROSENZWEIG, M. L., 1971, Paradox of enrichment: destabilization of exploitation ecosystems in ecological time. Science, 171: 385-387.

SCHOENNER, T. W., 1974, Resource partitioning in ecological communities. Science, 185: 27-39.

SCOTT, V. E., CROUCH, G. L. \& WHELAN, J. A., 1982, Responses of birds and small mammals to clearcutting in subalpine forest in central Colorado. Research note RM-422. Rocky Mountain Forest and Range Experiment Station, Fort Collins, Colorado.

SHER, A. A., MARSHALL, D. L. \& GILBERT, S. A., 2000, Competition between native Populus deltoides and invasive Tamarix ramosissima and the implications for reestablishing flooding disturbance. Conservation Biology, 14: 1744-1754.

SIMPSON, G. G., 1964, Species diversity of North America: Recent mammals. Systematic Zoology, vol. 13. pp. 57-73. In: Paglia, A. P., De Marco, P. Jr., Costa, F. M., Pereira, R. F., Lessa, G. (1995): Heterogeneidade estrutural e diversidade de pequenos mamíferos em um fragmento de mata secundária em Minas Gerais. Revista Brasileira de Zoologia, 12: 67-79.

SOUSA, W. P., 1984, The role of disturbance in natural communities. Annual Review in Ecology and Sistematics, 15: 353-391.

STALLINGS, J. R., PINTO, L. P. S., AGUIAR, L. \& SÁBATO, E. L., 1990, A importância dos distúrbios intermediários na manutenção da diversidade da fauna em uma floresta tropical. In: Martins, R. P., Lopes, F. S. (eds.) Atas do encontro de ecologia evolutiva. São Paulo, Academia de Ciências de São Paulo, Publicações ACIESP, 69: 43-48. In: Paglia, AP, De Marco, P., Jr., Costa, F. M., Pereira, R. F., Lessa, G. (1995), Heterogeneidade estrutural e diversidade de pequenos mamíferos em um fragmento de mata secundária em Minas Gerais. Revista Brasileira de Zoologia. 12: 67-79.

STEVENS, S. M. \& HUSBAND, T. P.,1998, The influence of edge on small mammals: evidence from Brazil Atlantic forest fragments. Biological Conservation, 85: 1-8.

TERBORGH, J., 1992, Maintenance of tropical forests. Biotropica, 24: 283-292.

TURNER, I. M., 1996, Species loss in fragments of tropical rain forest. A Review of the Evidence. J. Appl. Ecol. 33, 200-209.

WHITMORE, T. C., 1997, Tropical forest disturbance, disappearance and species loss. pp. 3-12. In: Laurence, W. F. \& Bierregaard, R. O. Jr., (eds.): Tropical Forest Remnants. The University of Chicago Press, Chicago.

WYLIE, J. L. \& CURRIE, D. J., 1993, Species-energy theory and patterns of species richness: Patterns of Bird, angiosperm and mammal richness on islands. Biological Conservation, 63: 137-144.

YAHNER, R. H., 1986, Microhabitat use by small mammals in even-aged forest stands. The American Midland Naturalist, 115: 174-180.

YAHNER, R. H., 1984, Effects of habitat patchiness created by a Ruffed Grouse Management Plan On Breeding Bird Communities. American Midland Naturalist, 111: 409413. 